Editorial

\title{
Raanan Gillon: editor for twenty years
}

Tony Hope University of Oxford

Raanan Gillon is stepping down as editor of this journal after twenty years. Thirty years ago he had the vision to see that critical thinking in ethics should be central to medical practice. Through his enormous abilities as writer, editor, philosopher and doctor he has been one of the pioneers, working in the UK, who has made that vision a reality.

In the 1970s many medical schools in the UK set up student-run groups that focused on medical ethics. These followed the lead given by Ted Shotter who had founded the flagship London Medical Group. I first met $\mathrm{Ra}$ when he was the keynote speaker at a national conference of these student groups in Windsor Great Park. I was a medical student at the time. After Ra's talk I asked a question, which $\mathrm{Ra}$ answered perfectly satisfactorily. In the afternoon, when we were let off the hook (so that Ted could watch the Oxford versus Cambridge Boat Race), Ra suggested that we go for a walk. He thought that I deserved a fuller answer to my question. I was greatly impressed by the careful thought, lively interest, and time, that he gave to the issue that I had raised.

I came to know Ra very well when I joined him as associate editor of this journal. Shortly after I started, he sent me a paper to review. He told me that this was a paper by a young doctor who had not previously published in medical ethics. He was keen to be encouraging. If I did not think the paper should be taken by the journal as it was, could I provide constructive feedback so the author could develop the article with a view to publication? The example and lead that $\mathrm{Ra}$ gave were clear. $\mathrm{He}$ wanted the journal to increase the profile of medical ethics through good quality articles. But he also wanted to encourage young authors. Ra has always gone to considerable trouble to help young authors to develop their ideas.

For 18 of the 20 years that $\mathrm{Ra}$ has been editor I have been his assistant, and I have decided that it is the right time for me to step down as well. I would like to take this opportunity to thank Maureen Bannatyne (editorial assistant) and Ann Lloyd (technical editor) who both combine total efficiency with unfailing supportive good humour. Working with them has been one of the pleasures of my time at the Fournal of Medical Ethics. As associate editor my role has been looking after book reviews (until Mike Parker took over this post a year ago); acting occasionally as referee over an editorial decision, and, since the journal expanded to become a bimonthly, writing two editorials a year.

One disappointment for me has been the difficulty we have had in attracting articles for our "At the coal face: medical ethics in practice" series. The idea behind this series is to encourage clinicians to describe real situations that raise ethical problems without the burden of undertaking much, or indeed any, philosophical analysis. Such cases might be valuable in two ways: first, to enable clinicians, unwilling or unable to provide analysis themselves, to identify situations that would benefit from ethical discussion; second, to stimulate philosophers to use real examples in their own theoretical work. Bill Fulford, Professor of Philosophy and Mental Health at the University of Warwick, has frequently emphasised this two-way interchange between philosophy and medical practice, particularly in the area of psychiatry.

However, the achievements of the journal greatly outweigh this disappointment. One such achievement has been the publishing of articles that are not only understandable and relevant to clinicians who have no training in medical ethics, but which also advance the philosophical literature. As the quantity of sophisticated articles in medical ethics increases it will remain a challenge for the journal to continue to attract philosophically good articles without losing its general medical readership. A second achievement has been the major role that the journal has played in developing the teaching of medical ethics. Many years before ethics was identified by the General Medical Council (GMC) as part of the core curriculum for UK medical students the journal was publishing articles describing pioneering courses from around the world. A third achievement has been the fostering of research that combines empirical methodology with medical ethics. This is a type of research that is rapidly gaining in importance. Since such research uses two methodologies, those from the social sciences and those from philosophy, it can be particularly difficult for a journal to ensure that articles are fairly and thoroughly reviewed.

The achievements of the journal reflect Ra's dedication as an editor. However, it is not merely as an editor I have come to know him but as a friend. And one of his charms as a companion is his inexhaustible enjoyment of friendly argument, not only about issues in medical ethics but around almost any disputable subject (and even around some that 
are not). This is perhaps not surprising given that he is descended on one side of his family from a long line of rabbis, and on the other side from the Dean of Christ Church in Oxford. Ra seems never so happy as over the dinner table, surrounded by family and friends, good food, and a bottle or two of wine. He is a man with Falstaff's energy, though not his girth, and, like Falstaff he is not only witty in himself but the cause of wit in others.

On qualifying in medicine $\mathrm{Ra}$ spent seven years as a professional medical journalist, followed by that medical baptism by fire: junior hospital jobs. He then studied part-time for a philosophy degree at London University, getting a top first. No wonder he was the perfect appointment for editor of the fournal of Medical Ethics.

Ra's writing speaks to doctors. This is one reason why he has been so effective in convincing a somewhat conservative profession of the importance and relevance of ethics. Throughout his time as editor of this journal he has worked as a general practitioner. He knows what it is like to be a docto and he knows how doctors think. I have always found a certain refreshing "surgical" quality to his approach-no nonsense, clarity, and cutting through sloppy thinking. Again and again over the last twenty years doctors have told me how much they enjoyed an article by Ra: they could see the relevance of medical ethics to clinical practice, often for the first time.

People read Ra's articles not only because they are clear and relevant. He simply writes so well. An article for the British Medical fournal on resource allocation started with his asking his eight-year-old daughter: "'How should I choose one out of three dying people to have the only available lifesaving machine?' 'Well,' she told me, sparing a moment or two from her television programme, 'you could give it to the youngest because she'd live longer (welfare maximisation), or you could give it to the kindest because kind people deserve to be treated nicely (merit). No, you couldn't give it to the one you liked best (partiality), that wouldn't be fair'."

In order to achieve what Ra has achieved ability is not enough. Enormous energy is required. In addition to a clinical commitment that has been at least half-time, and the ever-increasing work of editing the JME, Ra has published extensively, spoken at innumerable conferences (both national and international), and worked on committees and groups, all towards the aim of ensuring that critical thinking in ethics should be placed at the heart of medicine. His book Philosophical Medical Ethics, which developed from a series of articles for the British Medical fournal remains, after 15 years, one of the best introductions to medical ethics. It has been reprinted nine times. The enormous, edited, Principles of Health Care Ethics, with ninety chapters, is one of the major source-books in medical ethics: my first copy was stolen (or at any rate borrowed and never returned) which is always a good indicator of the real worth of a book. The eighty editorials for the JME represent only a small proportion of his written output. Frequent articles in mainstream clinical journals, and especially the British Medical fournal, have brought the relevance of ethics to the notice of practising doctors. There are also thirty or so chapters in books, fifty articles in refereed journals, a key role in developing a core curriculum for ethics and law in medical training; and much else.

I am just one of those who have benefited from Ra's enormous capacity to encourage and help those around him. Ra's achievements for this journal and for medical ethics worldwide have been enormous. I wish him all the best on his retirement as editor of the Fournal of Medical Ethics. 